BMJ Open

Sport \&

Exercise

Medicine

\title{
Deaths in triathletes: immersion pulmonary oedema as a possible cause
}

\author{
Richard E Moon, ${ }^{1}$ Stefanie D Martina, ${ }^{2}$ Dionne F Peacher, ${ }^{3}$ William E Kraus ${ }^{4}$
}

To cite: Moon RE, Martina SD, Peacher DF, et al. Deaths in triathletes: immersion pulmonary oedema as a possible cause. BMJ Open Sport Exerc Med 2016;2:e000146.

doi:10.1136/bmjsem-2016000146

- Prepublication history and additional material is available. To view please visit the journal (http://dx.doi.org/ 10.1136/bmjsem-2016000146).

Accepted 2 August 2016

\section{ABSTRACT \\ Background/aim: To address the question as to whether immersion pulmonary oedema (IP0) may be a common cause of death in triathlons, markers of swimming-induced pulmonary oedema (SIPO) susceptibility were sought in triathletes' postmortem examinations.}

Methods: Deaths while training for or during triathlon events in the USA and Canada from October 2008 to November 2015 were identified, and postmortem reports requested. We assessed obvious causes of death; the prevalence of left ventricular hypertrophy (LVH); comparison with healthy triathletes.

Results: We identified 58 deaths during the time period of the review, $42(72.4 \%)$ of which occurred during a swim. Of these, 23 postmortem reports were obtained. Five individuals had significant $(\geq 70 \%)$ coronary artery narrowing; one each had coronary stents; retroperitoneal haemorrhage; or aortic dissection. 9 of $20(45 \%)$ with reported heart mass exceeded 95th centile values. LV free wall and septal thickness were reported in 14 and 9 cases, respectively; of these, 6 (42.9\%) and 4 (44.4\%) cases exceeded normal values. 6 of 15 individuals $(40 \%)$ without an obvious cause of death had excessive heart mass. The proportion of individuals with LVH exceeded the prevalence in the general triathlete population.

Conclusions: LVH—a marker of SIPO susceptibilitywas present in a greater than the expected proportion of triathletes who died during the swim portion. We propose that IPO may be a significant aetiology of death during the swimming phase in triathletes. The importance of testing for LVH in triathletes as a predictor of adverse outcomes should be explored further.

\section{INTRODUCTION}

The triathlon is a sequence of consecutive races consisting of a sequence of swim (750$3800 \mathrm{~m})$, bicycle $(13-112 \mathrm{~km})$ and foot (5-42 km) races. As in all competitive sports, there is a modest sudden death rate, which has been estimated at 1.5 per 100000 participants, ${ }^{1}$ in sanctioned triathlon events, two to three times greater than the marathon rate. $^{2}{ }^{3}$ As most deaths occur during the swim when the victim's plight is not readily distinguishable among the large number of swimmers, the proximate cause of sudden

\section{What are the new findings?}

In a series of deaths occurring during the swim portion of triathlon events, a high proportion of autopsies demonstrated cardiac anomalies, in particular left ventricular hypertrophy (LVH). LVH is a marker of immersion pulmonary oedema (IPO) susceptibility, and the authors propose that many of these deaths were due to swimming-induced pulmonary oedema (SIPO).

How might it impact on clinical practice in the near future?

The results suggest that screening examinations for triathletes should search for conditions that predispose to SIPO, such as hypertension, LVH and obstructive sleep apnoea. A risk reduction strategy that may prevent some of these deaths should include optimisation of blood pressure and body weight, and treatment of sleep apnoea.

death in the swim portion of the triathlon remains elusive.

Drowning, the process of experiencing respiratory impairment from submersion/ immersion in liquid, ${ }^{4}$ is often the official reported cause of swimming death; ${ }^{1}$ however, drowning seems unlikely in experienced swimmers. Predictors of cardiac death-the overwhelming primary cause of sudden death in most other sports ${ }^{2}{ }^{5-8}$-remain elusive in triathletes. Arrhythmic causes, including prolonged QTc and autonomic conflict (simultaneous activation of sympathetic and parasympathetic), ${ }^{4} 9$ have been proposed in triathlete cardiac death. Other suggested causes include exertional heat stroke, myocardial infarction, head trauma, panic attack and arrhythmia. ${ }^{10}$ Cause of death uncommonly can be attributed to an anatomic cardiac anomaly; ${ }^{1}$ thus, in most cases, physiological causes must be sought.

Immersion pulmonary oedema (IPO, also known as swimming-induced pulmonary oedema, SIPO) is one such potential cause. IPO presents as rapid onset of dyspnoea, 
wheezing, hypoxaemia and expectoration of blood-tinged sputum, which can incapacitate a swimmer. A recent comprehensive review of swimming-related death identified IPO as a possible cause. ${ }^{11}$ Although IPO usually occurs in healthy individuals without an obvious predisposing factor, many victims have left ventricular hypertrophy (LVH), hypertension and other cardiovascular comorbidities-potential markers of susceptibility. ${ }^{12-15}$

The current investigation was performed to test the hypothesis that, when compared with healthy triathletes and the general population, individuals who died during a triathlon or in training have a higher prevalence of cardiac anomalies that could predispose to IPO.

\section{METHODS}

The study was approved by the Duke Medicine Institutional Review Board. Using the search phrase 'triathlon death', deaths during triathlon events or while in training for triathlons in the USA and Canada from October 2008 to November 2015 were identified using manual internet searches and Google Alerts. The phase of the event when death occurred was obtained from news sources such as newspaper articles or internet postings. Medical examiner reports for those participants who died during a swim were requested, and the phase of the race in which each acute event occurred was confirmed from the report.

Each medical examiner report was examined to determine whether there were any abnormalities of coronary arteries, cardiac muscle or valves, or obvious cause of death other than coronary disease. Heart mass and myocardial thickness were recorded. Heart mass was classified relative to normal reference ranges: for men 233$383 \mathrm{~g} ;{ }^{16}$ for women $148-296 \mathrm{~g} .{ }^{17}$ Heart mass and ventricular wall thickness were also compared with the 95th centile values of normal heart mass scaled to height and sex. ${ }^{18}$ Values also were compared with echocardiographic data obtained from a population of triathletes. ${ }^{19}$ Also recorded were age, sex, height, body mass, body mass index, event date, death date, autopsy results and any other available pertinent information. Significant coronary artery disease (CAD) was enumerated as $\geq 70 \%$; $\geq 50 \%$ coronary narrowing was also recorded. ${ }^{20} \mathrm{LV}$ mass was conservatively estimated as $75 \%$ of total heart weight. ${ }^{21}$

Statistical comparisons of categorical variables were performed using $\chi^{2}$ test or Fisher's exact test (JMP Pro V. 12.1.0: SAS Institute, Cary, North Carolina, USA).

\section{RESULTS}

We identified 58 deaths during the time period of the review, of which $42(72.4 \%)$ occurred during the swim (tables 1 and 2). A total of 23 medical examiner reports were obtained and reviewed. There were 19 men and 4 women (table 3). The age distribution of the population of individuals for whom medical examiner report was available did not differ from the total population of swimming deaths (table $4, \chi^{2}=1.274, p=0.74$ ). Further
Table 1 Distribution of sex and age (years) in all recorded triathlon deaths

\begin{tabular}{llll}
\hline & Males & Females & Total \\
\hline $\mathrm{N}$ & 49 & 9 & 58 \\
Mean (SD) & $49.5(11.8)$ & $41.8(7.0)$ & $48.3(11.5)$ \\
Range & $28-76$ & $31-54$ & $28-76$ \\
\hline
\end{tabular}

Table 2 Activity in which death occurred

\begin{tabular}{lccc}
\hline Activity & $\begin{array}{l}\text { Death during } \\
\text { training }\end{array}$ & $\begin{array}{l}\text { Death during } \\
\text { event }\end{array}$ & $\begin{array}{l}\text { Total } \\
\text { deaths } \\
\mathbf{N}(\%)\end{array}$ \\
\hline Swim & $3(30)$ & $39(81.3)$ & $42(72.4)$ \\
Bike & $5(50)$ & $6(12.5)$ & $11(19.0)$ \\
Run & $2(20)$ & $3(6.3)$ & $5(8.6)$ \\
Total & $10(100.0)$ & $48(100.0)$ & $58(100.0)$ \\
\hline
\end{tabular}

Table 3 Sex distribution of all swimming deaths and deaths for which medical examiner report was available

\begin{tabular}{lll}
\hline Sex & All swimming deaths & $\begin{array}{l}\text { Autopsied deaths } \\
\mathbf{N}(\%)\end{array}$ \\
\hline Male & $36(85.7)$ & $19(82.6)$ \\
Female & $6(14.3)$ & $4(17.4)$ \\
Total & $42(100.0)$ & $23(100.0)$ \\
\hline
\end{tabular}

Table 4 Age distribution of all swimming deaths and deaths for which medical examiner report was available

\begin{tabular}{lcc}
\hline $\begin{array}{l}\text { Age } \\
\text { range }\end{array}$ & $\begin{array}{l}\text { All swimming } \\
\text { deaths } \\
\mathbf{N}(\%)\end{array}$ & $\begin{array}{l}\text { Swimming deaths with } \\
\text { medical examiner report } \\
\mathbf{N}(\%)\end{array}$ \\
\hline$<40$ & $4(9.5)$ & $2(8.7)$ \\
$40-49$ & $16(38.1)$ & $12(52.2)$ \\
$50-59$ & $13(31.0)$ & $5(21.7)$ \\
$\geq 60$ & $9(21.4)$ & $4(17.4)$ \\
Total & $42(100.0)$ & $23(100.0)$ \\
\hline
\end{tabular}

details are provided in table 5 and the online supplementary file.

Among the population of swimming deaths, the age distribution in individuals for whom medical examiner report was available did not differ from the total population of swimming deaths ( $p=0.73$, Fisher's exact test).

Four individuals had significant $(\geq 70 \%)$ CAD. A man aged 58 years died of a massive retroperitoneal haemorrhage due to renal artery dissection. Death was attributed to acute dissection of the descending aorta in a man aged 66 years. A man aged 46 years had a history of atrial fibrillation, and flecainide was detected in his urine. A man aged 68 years was known to have coronary stents; his death was presumed to have been due to 


\begin{tabular}{|c|c|c|c|c|c|c|c|c|c|c|c|c|}
\hline Categories & $\mathbf{N}$ & $\begin{array}{l}\text { Age } \\
\text { Mean } \\
\text { (SD), } \\
\text { range } \\
\text { (years) }\end{array}$ & $\begin{array}{l}\text { Height } \\
\text { Mean (SD), } \\
\text { range } \\
\text { (months) }\end{array}$ & $\begin{array}{l}\text { Weight } \\
\text { Mean (SD), } \\
\text { range (kg) }\end{array}$ & $\begin{array}{l}\text { BMI } \\
\text { Mean (SD), } \\
\text { range (kg/ } \\
\left.\mathbf{m}^{2}\right)\end{array}$ & $\begin{array}{l}\text { Heart mass } \\
\text { Mean (SD), } \\
\text { range }(g)\end{array}$ & $\begin{array}{l}\text { Heart } \\
\text { mass } \\
\text { Greater } \\
\text { than } \\
\text { normal }^{\star}\end{array}$ & $\begin{array}{l}\text { CAD: } \\
\geq 70 \% \\
\text { narrowing } \\
\text { in any } \\
\text { coronary } \\
\text { artery }^{20}\end{array}$ & $\begin{array}{l}\text { CAD: } \\
\geq 50 \% \\
\text { narrowing } \\
\text { in any } \\
\text { coronary } \\
\text { artery }^{20}\end{array}$ & $\begin{array}{l}\text { RV } \\
\text { thicknesst } \\
\text { Mean (SD), } \\
\text { range } \\
(\mathrm{mm}), \mathrm{N}\end{array}$ & $\begin{array}{l}\text { LV } \\
\text { thicknesst } \\
\text { Mean (SD), } \\
\text { range } \\
(\mathrm{mm}), \mathrm{N}\end{array}$ & $\begin{array}{l}\text { Septal } \\
\text { thickness } \\
\text { Mean (SD), } \\
\text { range } \\
(\mathrm{mm}), \mathrm{N}\end{array}$ \\
\hline All & 23 & $\begin{array}{l}49.5(9.6) \\
33-68\end{array}$ & $\begin{array}{l}1.77(0.07) \\
1.63-1.93\end{array}$ & $\begin{array}{l}96.2(32.1) \\
51.7-199.6\end{array}$ & $\begin{array}{l}30.9 \text { (11.7), } \\
15.9-75.5\end{array}$ & $\begin{array}{l}447.6(82.7) \\
290-630\end{array}$ & $\begin{array}{l}20 / 21 \\
(95.2 \%)\end{array}$ & $\begin{array}{l}5 / 22 \\
(22.7 \%)\end{array}$ & $\begin{array}{l}7 / 22 \\
(31.8 \%)\end{array}$ & $\begin{array}{l}4.0(1.6) \\
2-8, N=12\end{array}$ & $\begin{array}{l}14.6(5.2) \\
10-26 \\
N=14\end{array}$ & $\begin{array}{l}15.7(6.5) \\
8-26, N=9\end{array}$ \\
\hline White & 21 & & & & & & & & & & & \\
\hline Male & 18 & $\begin{array}{l}51.6(9.9) \\
33-68\end{array}$ & $\begin{array}{l}1.80(0.05) \\
1.70-1.93\end{array}$ & $\begin{array}{l}95.8(20.5) \\
69.7-142.5\end{array}$ & $\begin{array}{l}29.5(4.8) \\
23.4-38.3\end{array}$ & $\begin{array}{l}462.4(77.0) \\
290-630\end{array}$ & $\begin{array}{l}14 / 15 \\
(93.3 \%)\end{array}$ & $\begin{array}{l}5 / 17 \\
(29.4 \%) \ddagger\end{array}$ & $\begin{array}{l}7 / 17 \\
(41.2 \%) \ddagger\end{array}$ & $\begin{array}{l}5.5(2.1) \\
3-8, N=10\end{array}$ & $\begin{array}{l}18.3(8.4) \\
10-26 \\
N=11\end{array}$ & $\begin{array}{l}13.0(18.4), \\
10-26, N=7\end{array}$ \\
\hline Female & 3 & $\begin{array}{l}40.3(2.5) \\
38-43\end{array}$ & $\begin{array}{l}1.71(0.08) \\
1.65-1.80)\end{array}$ & $\begin{array}{l}71.4(17.4) \\
51.7-84.8\end{array}$ & $\begin{array}{l}24.9(8.0) \\
15.9-31.1\end{array}$ & $\begin{array}{l}363.7 \text { (92.1), } \\
310-470\end{array}$ & $\begin{array}{l}3 / 3 \\
(100 \%)\end{array}$ & 0/3 (0\%) & 0/3 (0\%) & $\begin{array}{l}2.5(0.7) \\
2-3, N=2\end{array}$ & $\begin{array}{l}12.7(3.8), \\
10-17, N=3\end{array}$ & $\begin{array}{l}8.5(0.7) \\
8-9, N=2\end{array}$ \\
\hline Black & 2 & & & & & & & & & & & \\
\hline Male & 1 & $\begin{array}{l}45.0(0.0) \\
\text { NA }\end{array}$ & $\begin{array}{l}1.73(0.0) \\
\text { NA }\end{array}$ & $\begin{array}{l}74.4(0.0) \\
\text { NA }\end{array}$ & $\begin{array}{l}24.9(0.0), \\
\text { NA }\end{array}$ & $\begin{array}{l}400.0(0.0) \\
\text { NA }\end{array}$ & $\begin{array}{l}1 / 1 \\
(100 \%)\end{array}$ & $0 / 1(0 \%)$ & 0/1 (0\%) & NR & NR & NR \\
\hline Female & 1 & $\begin{array}{l}44.0(0.0) \\
\text { NA }\end{array}$ & $\begin{array}{l}1.63(0.0) \\
\text { NA }\end{array}$ & $\begin{array}{l}199.6(0.0) \\
\text { NA }\end{array}$ & $\begin{array}{l}75.5(0.0) \\
\text { NA }\end{array}$ & $510(0.0), \mathrm{NA}$ & $\begin{array}{l}1 / 1 \\
(100 \%)\end{array}$ & $0 / 1(0 \%)$ & $0 / 1(0 \%)$ & $\mathrm{NR}$ & NR & NR \\
\hline
\end{tabular}

${ }^{*} \mathrm{LVH}$ defined as heart mass $>296 \mathrm{~g}$ (female), $>383 \mathrm{~g}$ (male).$^{16}$

†Myocardial thickness was not consistently reported. Where it was reported as a range, the average value was used.

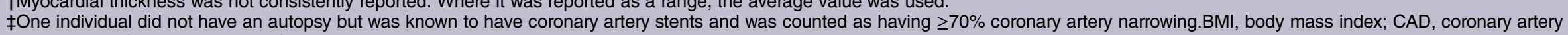
disease; LV, left ventricle; LVH, left ventricular hypertrophy; NA, not applicable; NR, not reported; RV, right ventricle. 
coronary disease and a full autopsy was not performed. Post-resuscitation ECG revealed prolonged QTc interval in a man aged 44 years whose initial cardiac rhythm was ventricular fibrillation. A woman aged 38 years had acute myocarditis. All individuals had pulmonary oedema.

Of 20 with reported heart mass and height, 9 (45\%) exceeded 95th centile values based on height. ${ }^{18} \mathrm{LV}$ free wall thickness was reported in 14 cases, and exceeded 95th centile $(1.49 \mathrm{~cm})$ in $6(42.9 \%)$; septal thickness was reported in 9 cases, and exceeded 95th centile $(1.69 \mathrm{~cm})$ in $4(44.4 \%)$.

Excluding those with an obvious possible cause of death (coronary disease $\geq 70 \%$ narrowing $(n=4)$, presumed coronary disease due to history of stent placement $(n=1)$, retroperitoneal haemorrhage $(n=1)$, aortic dissection $(\mathrm{n}=1)), 16$ individuals remained. Of these, 6 $(37.5 \%)$ had excessive heart mass, one of whom also had acute myocarditis. In this group, there was a higher proportion of individuals with thickened LV compared with the general triathlete population $(p<0.001$, table 6$)$.

The distributions of LV mass and septal thickness are shown in figure 1.

\section{DISCUSSION}

Albeit the probability of death during a triathlon is low, when occurring in a highly publicised event it inevitably

Table 6 Cardiac morphology in current series compared with echocardiographic data in 225 triathletes studied by Douglas ${ }^{19}$

\begin{tabular}{|c|c|c|c|c|c|}
\hline $\begin{array}{l}\text { Criterion for } \\
\text { LVH }\end{array}$ & $\begin{array}{l}\text { Per cent, } \\
\text { Douglas, } 1997^{19}\end{array}$ & $\begin{array}{l}\text { Per cent, current } \\
\text { series (all cases) }\end{array}$ & $\begin{array}{l}p \\
\text { Value }\end{array}$ & $\begin{array}{l}\text { Per cent, current series (CAD, } \\
\text { haemorrhage, aortic dissection } \\
\text { excluded) }\end{array}$ & $\begin{array}{l}p \\
\text { Value }\end{array}$ \\
\hline $\begin{array}{l}\text { Heart mass > } \\
\text { threshold }\end{array}$ & 24 & $45(\mathrm{~N}=20)$ & 0.023 & $37.5(\mathrm{~N}=16)$ & 0.1 \\
\hline $\begin{array}{l}\text { Septum } \\
\geq 1.3 \mathrm{~cm}\end{array}$ & 1 & $67(\mathrm{~N}=9)$ & $<0.001$ & $66.7(\mathrm{~N}=6)$ & $<0.001$ \\
\hline $\begin{array}{l}\text { Posterior wall } \\
\geq 1.3 \mathrm{~cm}\end{array}$ & 0.5 & $50(\mathrm{~N}=14)$ & $<0.001$ & $50(\mathrm{~N}=10)$ & $<0.001$ \\
\hline
\end{tabular}

Figure 1 Above: septal thickness from an echocardiographic study of participants in the Hawaii Ironman Triathlon ${ }^{19}$ and the present autopsy series; below: left ventricular mass reported by Douglas and estimated as $75 \%$ of heart weight at autopsy. ${ }^{21}$
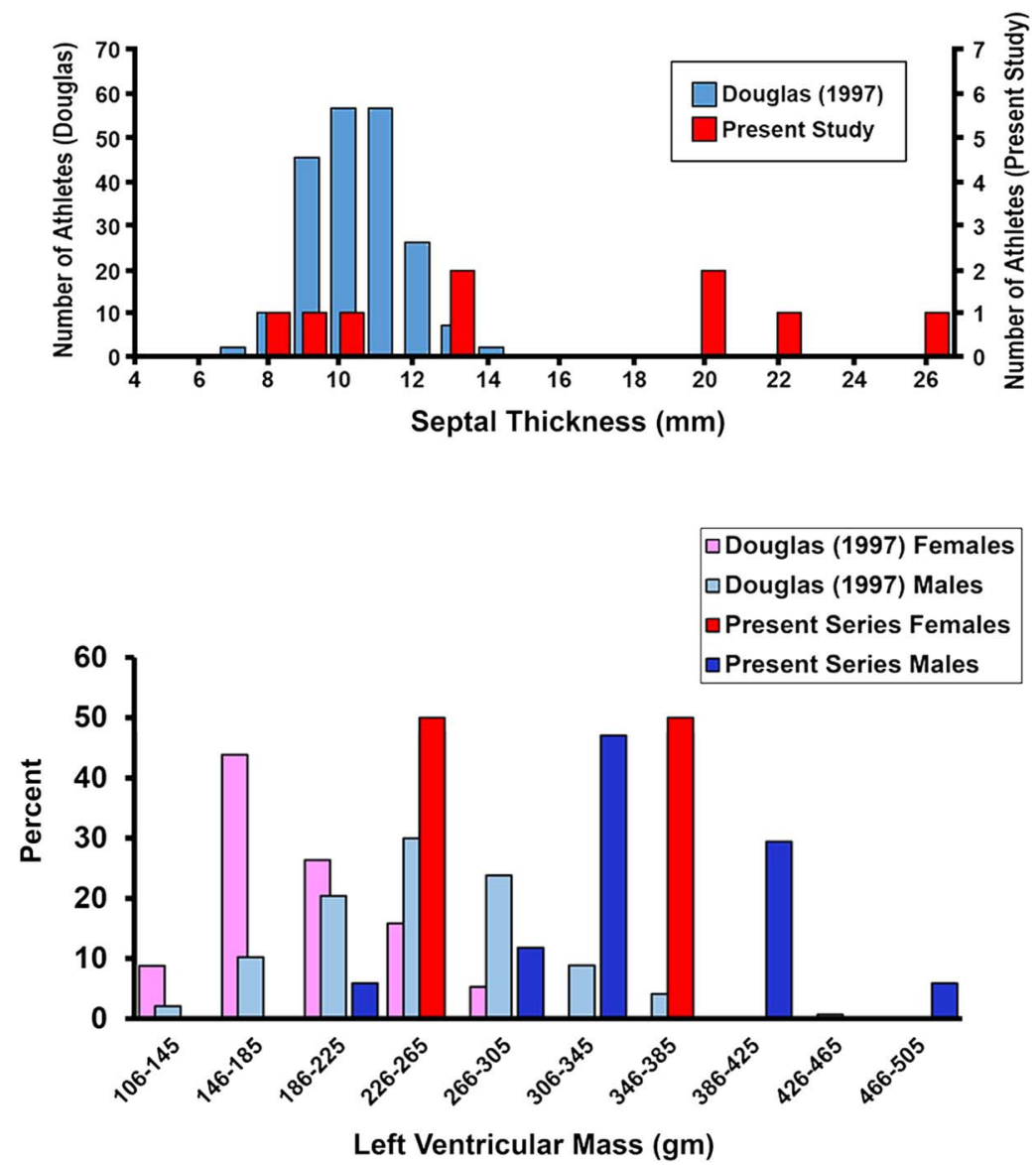
raises a great deal of public concern about the sport's safety. This impelled the largest North American triathlon organisation to initiate an inquiry into triathlon deaths. $^{22}{ }^{23}$ Unfortunately, good data are difficult to obtain and hence specific screening or aftercare recommendations could not be made. The current investigation was performed to test the hypothesis that, when compared with triathletes and the general population, individuals who died swimming during a triathlon or in training have a higher prevalence of cardiac anomalies that predispose to IPO.

\section{IPO and its causes}

Water immersion causes blood redistribution from the periphery to the heart and pulmonary vessels, causing an increase in central blood volume and pulmonary vascular pressures. ${ }^{24}$ This can be extreme and precipitate pulmonary oedema in IPO-susceptible individuals, even in those without any obvious comorbidities. ${ }^{25}$ The effect is augmented-especially during exercise-in cold versus warm water. ${ }^{26}$ Those triathletes susceptible to IPO are therefore believed to have abnormal myocardial diastolic compliance (lusitropy)—or stiff hearts. Abnormal LV diastolic compliance is partly responsible for elevated LV end-diastolic pressure during exercise in patients suffering from heart failure with preserved ejection fraction (HFpEF). ${ }^{27}$ IPO seems to be a form of HFpEF precipitated by increased preload due to immersion with heavy exertion. In the initial publication of IPO, a number of individuals exhibited a hypertensive response to cold exposure; thus, it is plausible that they had $\mathrm{LVH}^{12}$ In a recent review of published cases, nearly $50 \%$ of published civilian IPO cases had identifiable predisposing factors, and most were cardiac. ${ }^{15}$ The association of IPO susceptibility with $\mathrm{LVH}$ and risk factors for $\mathrm{LVH}^{12-15}$ strongly implicates abnormal LV diastolic compliance.

Since most sudden deaths occur during the swim portion of the triathlon, it is certainly plausible that IPO is a cause. IPO tends to occur in susceptible individuals most frequently in cold water, and often during heavy exertion. ${ }^{2} 28-30$ Typical IPO symptoms-cough productive of pink frothy or blood-tinged secretions occurring during a swim-have been reported by $1.4 \%$ of triathletes, ${ }^{31}$ and in $1.8-60 \%$ during $2.4-3.6 \mathrm{~km}$ open sea swimming trials in young, fit naval recruits. ${ }^{29} 32$

The prevalence of $\mathrm{LVH}$ in the general population is estimated to be $12-21 \% .{ }^{33} 34$ In well-trained triathletes, LV dimensions are usually within the normal range for the general population. ${ }^{19} 3536$ In a group of 235 triathletes (168 men, 67 women) participating in the Hawaii Ironman Triathlon from 1985 to 1995 , the overall prevalence of LVH by echocardiography was $24 \%$ (LV mass $>294 \mathrm{~g}$ in men, $>198 \mathrm{~g}$ in women). ${ }^{19}$ Chronic, highintensity exercise can also lead to LVH (athlete's heart); this was the most likely cause of the enlarged LV in most cases in the quoted series. Diastolic filling properties in athlete's heart under dry, resting conditions are normal; ${ }^{37} 38$ thus, it is unlikely that athlete's heart is a precipitating cause of IPO. LV thickness in athlete's heart very rarely exceeds $13 \mathrm{~mm} .{ }^{39}{ }^{40}$ In contrast, in the current series, a pathological cause of enlarged hearts was more prevalent, including extreme values of septal thickness and estimated LV mass (figure 1), significantly beyond the range expected from hypertrophy due to athlete's heart. ${ }^{36} 3941$ Thus, diastolic filling properties were more likely to be abnormal. All autopsied cases in this series had pulmonary oedema, which is usually the end result from any attempt at cardiopulmonary resuscitation and water aspiration during terminal event. Thus, the existence of pulmonary oedema at autopsy provides little insight.

\section{Possible causes of death in triathlons}

In some cases, cardiac anatomy at autopsy after a triathlon may occasionally provide clues to the cause of death. ${ }^{1}$ Of nine athletes autopsied after a triathlonrelated death, only two had cardiac anomalies that could be construed as being a primary cause of death: one with Wolff-Parkinson-White syndrome, the other with a congenital coronary artery anomaly. On the other hand, six had $\mathrm{LVH}^{1}$

IPO is a plausible cause of triathlon death, particularly since it has been suggested as one possible mechanism in the pathophysiology of drowning. ${ }^{4}$ In contrast, due to the rarity of IPO-related deaths and lack of known history of IPO in any triathlon death, some have concluded that it is an unlikely cause of death in triathletes. ${ }^{10} 2223$ Nevertheless, several IPO-related deaths have been reported in other settings. ${ }^{42-47}$ Fatal cases of IPO may be rare but probably under-recognised; unless an episode is witnessed and survival is sufficiently long enough to obtain adequate clinical information to make the diagnosis, attribution of an in-water death to IPO is exceedingly difficult. ${ }^{48}$

It is impossible to exclude primary arrhythmia as the cause of death in these individuals. Indeed, it has been proposed that cardiomegaly is an independent risk factor for cardiac arrhythmia. ${ }^{35}{ }^{49-51}$ However, in a series of cardiac arrests during long-distance runs (where diagnostic facilities are more likely to be available and thus early detection of an arrhythmia more likely), primary arrhythmia was the purported cause in only a minority of instances. Non-ischaemic ventricular tachycardia was observed in only $7 \%$, with 'presumed arrhythmia' the attributed cause in an additional $7 \% .^{3}$ One individual in our series had a history of atrial fibrillation and was taking an antiarrhythmic. It is not possible to know whether his propensity towards atrial arrhythmias contributed to his death; however, any rhythm other than sinus rhythm is likely to cause a rise in pulmonary artery and capillary pressures in the face of increased preload as occurs during immersion. In fact, atrial fibrillation has been proposed as a predisposing condition for IPO. ${ }^{52}$ In another case in the present series, prolonged QTc was noted after resuscitation. Swimming can be a trigger for arrhythmias in long QTc syndrome $;^{53}$ 
however, prolonged QTc could also be secondary to antiarrhythmic drug administration after cardiopulmonary resuscitation or the cardiac injury itself. Information about genetic predisposition was unavailable. On the other hand, additional information from bystanders and others suggests that at least some of the deaths in the current series were not sudden and had features consistent with IPO (eg, cases 2, 10, 23 in the online supplementary material).

It might also be argued that demand ischaemia might be more likely during swimming, even in those with minimal coronary narrowing, because of the central redistribution of blood and higher $\mathrm{LV}$ volume. For a given level of exercise, this might lead to greater myocardial wall tension and myocardial oxygen consumption compared to dry land. However, in patients with known $\mathrm{CAD}$, a study of swimming in cold water versus cycling demonstrated that ST segment depression occurred at similar levels of exercise during both activities. ${ }^{54}$

The distribution of cardiac pathologies in this series is in marked contrast with other similar studies: in younger cohorts of sudden death cases, myocarditis, hypertrophic cardiomyopathy (HCM) and coronary artery abnormalities are more common. ${ }^{55}$ In case series with age distribution similar to the current series, atherosclerotic disease predominates. ${ }^{56} 57$ Of those in our cohort in whom coronary arteries were mentioned in the medical examiner's report, only four individuals had $\geq 70 \%$ coronary narrowing; six individuals had $\geq 50 \%$ narrowing. One additional person who did not have an autopsy but had coronary artery stents was presumed to have $\geq 50 \%$ narrowing. Whereas HCM is a common cause of sudden cardiac death in most series of land-based athletic events, no mention of it was made in any of the medical examiner reports in this series. While it can be difficult to distinguish HCM from undifferentiated LVH at autopsy ${ }^{58}$ the apparent lack of HCM in this series is consistent with the physiology of swimming: blood redistribution during immersion dilates the LV and thus reduces the likelihood of $\mathrm{LV}$ outflow obstruction even when present.

\section{Limitations}

There are several limitations to our study showing that markers of IPO susceptibility are common among victims of sudden death during triathlons. It cannot be definitively concluded that the cause of death in individuals with LVH was IPO. IPO has been considered by some to be an unlikely cause of triathlon death due to lack of prior history among victims. However, instances of IPO are most likely under-reported. Most triathletes train for the swim portion in pools, which are generally warmer than open bodies of water where events are held, and during a pool swim mild IPO symptoms can be relieved at an early stage by exiting the water. Primary arrhythmias cannot be excluded; indeed, it has been suggested that arrhythmias are more common among individuals with $\mathrm{LVH}^{34}$
Among those classified as having no obvious cause of death, one (woman aged 38 years, see online supplementary case 3) had histologic evidence for acute myocarditis. Two others (man aged 57 years, see online supplementary case 6 and man aged 48 years, see online supplementary case 18 ) had $50-60 \%$ coronary stenosis. Although this degree of stenosis is not conventionally considered to be critical, the true degree of narrowing could have been underestimated at autopsy. Another (man aged 46 years, see online supplementary case 10 ) had no CAD but did have areas of myocardial fibrosis and chronic inflammation suggesting remote infarction. Finally, one case (man aged 43 years, see online supplementary case 12) had scattered intramural adipose and focal loose interstitial fibrous tissue. Although not identified as such by the examining pathologist, this could be consistent with arrhythmogenic right ventricular dysplasia. We cannot exclude the possibility that these individuals might have died of an arrhythmia.

While there could be inconsistencies in attempting to compare LVH using echocardiography with heart mass determined at autopsy (table 6), we feel that gross errors are unlikely as echo has been validated against postmortem measurements. ${ }^{59}$

Among 775 sports-related sudden death cases during moderate-to-vigorous exertion among men and women, fewer deaths occur during swimming than cycling or jogging. ${ }^{60}$ This could be a consequence, in individuals at risk for athletic sudden death, of fewer person-hours spent swimming. However, in triathlons, a specific swimming-related mechanism for death would be expected to predominate where swimming is the first of three events.

Nevertheless, observations demonstrating that IPO is relatively common in competitive swimming such as military training and triathlons-and has been the cause of deaths ${ }^{42-47}$-implicate this condition as a likely cause of at least some deaths in triathlons. It would have been ideal to compare autopsies of triathletes dying during the bicycle or run portions; however, this was not possible due to fewer of those deaths, with a significant proportion due to motor vehicle trauma. Interestingly, scuba diving is another precipitating activity for IPO; indeed, LVH has been observed in a high percentage of scuba diving deaths. ${ }^{61}$

\section{Conclusion}

In a series of sudden deaths occurring during triathlon training or events, we found evidence on postmortem examination of a prevalence of IPO susceptibility markers $(\mathrm{LVH})$ in excess of the prevalence expected among healthy triathletes. We suspect that IPO may be a significant cause of death in triathletes. Analogous to the management of HFpEF, the goal should be to seek and eliminate pertinent risk factors such as hypertension, obesity and obstructive sleep apnoea. ${ }^{62}$ Educational programmes to promulgate information about risk factors could raise awareness and reduce the risk in this population. 
Author affiliations

${ }^{1}$ Departments of Anesthesiology and Medicine, Duke University Medical Center, Durham, North Carolina, USA

${ }^{2}$ Department of Surgery, Duke University Medical Center, Durham, North Carolina, USA

${ }^{3}$ Department of Anesthesia, University of lowa, lowa City, Iowa, USA ${ }^{4}$ Department of Medicine, Division of Cardiology, Duke Molecular Physiology Institute, Duke University Medical Center, Durham, North Carolina, USA

\section{Twitter Follow Richard Moon at @RichardEMoon}

Acknowledgements The authors are grateful to the numerous medical examiners' offices that provided the reports.

Contributors REM initiated the study, analysed the data and wrote the manuscript. SDM assisted with data collection and manuscript editing. DFP assisted with data analysis. WEK provided expert input and edited the manuscript.

Funding US Naval Sea Systems Command N0463A-07-C-0002 and N61331-03-C-0015.

\section{Competing interests None declared.}

Ethics approval Duke Medicine Institutional Review Board.

Provenance and peer review Not commissioned; externally peer reviewed.

Data sharing statement No additional data are available.

Open Access This is an Open Access article distributed in accordance with the Creative Commons Attribution Non Commercial (CC BY-NC 4.0) license, which permits others to distribute, remix, adapt, build upon this work noncommercially, and license their derivative works on different terms, provided the original work is properly cited and the use is non-commercial. See: http:// creativecommons.org/licenses/by-nc/4.0/

\section{REFERENCES}

1. Harris KM, Henry JT, Rohman E, et al. Sudden death during the triathlon. JAMA 2010;303:1255-7.

2. Redelmeier DA, Greenwald JA. Competing risks of mortality with marathons: retrospective analysis. BMJ 2007;335:1275-7.

3. Kim JH, Malhotra R, Chiampas G, et al. Cardiac arrest during long-distance running races. N Engl J Med 2012;366:130-40.

4. Bierens JJ, Lunetta P, Tipton M, et al. Physiology of drowning: a review. Physiology (Bethesda) 2016;31:147-66.

5. Maron BJ. Sudden death in young athletes. N Engl J Med 2003;349:1064-75

6. Tunstall Pedoe DS. Marathon cardiac deaths : the London experience. Sports Med 2007;37:448-50.

7. Marijon E, Tafflet M, Celermajer DS, et al. Sports-related sudden death in the general population. Circulation 2011;124:672-81.

8. Toukola T, Hookana E, Junttila J, et al. Sudden cardiac death during physical exercise: characteristics of victims and autopsy findings. Ann Med 2015;47:263-8.

9. Tipton MJ. Sudden cardiac death during open water swimming. Br J Sports Med 2014;48:1134-5.

10. Eichner ER. The mystery of swimming deaths in athletes. Curr Sports Med Rep 2011;10:3-4.

11. Asplund CA, Creswell LL. Hypothesised mechanisms of swimming-related death: a systematic review. Br J Sports Med. Published Online First: 3 Mar 2016. doi:10.1136/bjsports-2015094722.

12. Wilmshurst PT, Nuri M, Crowther A, et al. Cold-induced pulmonary oedema in scuba divers and swimmers and subsequent development of hypertension. Lancet 1989;1:62-5.

13. Gempp E, Louge P, Henckes A, et al. Reversible myocardial dysfunction and clinical outcome in scuba divers with immersion pulmonary edema. Am J Cardiol 2013;111:1655-9.

14. Gempp E, Demaistre S, Louge P. Hypertension is predictive of recurrent immersion pulmonary edema in scuba divers. Int $J$ Cardiol 2014;172:528-9.

15. Peacher DF, Martina SD, Otteni CE, et al. Immersion pulmonary edema and comorbidities: case series and updated review. Med Sci Sports Exerc 2015;47:1128-34.

16. Molina DK, DiMaio VJ. Normal organ weights in men: part l-the heart. Am J Forensic Med Pathol 2012;33:362-7.
17. Molina DK, DiMaio VJ. Normal organ weights in Women: part I-The Heart. Am J Forensic Med Pathol 2015;36:176-81.

18. Kitzman DW, Scholz DG, Hagen PT, et al. Age-related changes in normal human hearts during the first 10 decades of life. Part II (Maturity): a quantitative anatomic study of 765 specimens from subjects 20 to 99 years old. Mayo Clin Proc 1988;63:137-46.

19. Douglas PS, O'Toole ML, Katz SE, et al. Left ventricular hypertrophy in athletes. Am J Cardiol 1997;80:1384-8.

20. Lipinski M, Do D, Morise A, et al. What percent luminal stenosis should be used to define angiographic coronary artery disease for noninvasive test evaluation? Ann Noninvasive Electrocardiol 2002;7:98-105.

21. Murphy ML, White HJ, Meade J, et al. The relationship between hypertrophy and dilatation in the postmortem heart. Clin Cardiol 1988;11:297-302.

22. Medical Panel Report. USA triathlon fatality incidents study. 2012 edn. USA: Triathlon, 2012.

23. Dressendorfer R. Triathlon swim deaths. Curr Sports Med Rep 2015;14:151-2.

24. Arborelius M Jr, Ballidin UI, Lilja B, et al. Hemodynamic changes in man during immersion with the head above water. Aerosp Med 1972:43:592-8.

25. Moon RE, Martina SD, Peacher DF, et al. Swimming-induced pulmonary edema: pathophysiology and risk reduction with sildenafil. Circulation 2016;133:988-96.

26. Wester TE, Cherry AD, Pollock NW, et al. Effects of head and body cooling on hemodynamics during immersed prone exercise at 1 ATA. J Appl Physiol 2009;106:691-700.

27. Borlaug BA, Jaber WA, Ommen SR, et al. Diastolic relaxation and compliance reserve during dynamic exercise in heart failure with preserved ejection fraction. Heart 2011;97:964-9.

28. Hampson NB, Dunford RG. Pulmonary edema of scuba divers. Undersea Hyperb Med 1997;24:29-33.

29. Adir Y, Shupak A, Gil A, et al. Swimming-induced pulmonary edema: clinical presentation and serial lung function. Chest 2004;126:394-9.

30. Koehle MS, Lepawsky M, McKenzie DC. Pulmonary oedema of immersion. Sports Med 2005;35:183-90.

31. Miller CC 3rd, Calder-Becker K, Modave F. Swimming-induced pulmonary edema in triathletes. Am J Emerg Med 2010;28:941-6.

32. Shupak A, Weiler-Ravell D, Adir Y, et al. Pulmonary oedema induced by strenuous swimming: a field study. Respir Physiol 2000;121:25-31.

33. Levy D, Savage DD, Garrison RJ, et al. Echocardiographic criteria for left ventricular hypertrophy: the Framingham Heart Study. $A m$ J Cardiol 1987;59:956-60.

34. Laukkanen JA, Khan H, Kurl S, et al. Left ventricular mass and the risk of sudden cardiac death: a population-based study. J Am Heart Assoc 2014;3:e001285.

35. Claessens $\mathrm{P}$, Claessens $\mathrm{C}$, Claessens $\mathrm{M}$, et al. Ventricular premature beats in triathletes: still a physiological phenomenon? Cardiology 1999;92:28-38.

36. Whyte GP, George K, Sharma S, et al. The upper limit of physiological cardiac hypertrophy in elite male and female athletes: the British experience. Eur J Appl Physiol 2004;92:592-7.

37. Colan SD, Sanders SP, MacPherson D, et al. Left ventricular diastolic function in elite athletes with physiologic cardiac hypertrophy. J Am Coll Cardiol 1985;6:545-9.

38. Simsek Z, Hakan Tas M, Degirmenci $\mathrm{H}$, et al. Speckle tracking echocardiographic analysis of left ventricular systolic and diastolic functions of young elite athletes with eccentric and concentric type of cardiac remodeling. Echocardiography 2013;30:1202-8.

39. Pelliccia A, Maron BJ, Spataro A, et al. The upper limit of physiologic cardiac hypertrophy in highly trained elite athletes. N Engl J Med 1991;324:295-301.

40. Maron BJ, Pelliccia A, Spirito P. Cardiac disease in young trained athletes. Insights into methods for distinguishing athlete's heart from structural heart disease, with particular emphasis on hypertrophic cardiomyopathy. Circulation 1995;91:1596-601.

41. Caselli S, Di Paolo FM, Pisicchio C, et al. Three-dimensional echocardiographic characterization of left ventricular remodeling in Olympic athletes. Am J Cardiol 2011;108:141-7.

42. Cochard G, Arvieux J, Lacour JM, et al. Pulmonary edema in scuba divers: recurrence and fatal outcome. Undersea Hyperb Med 2005;32:39-44.

43. Henckes A, Lion F, Cochard G, et al. [Pulmonary oedema in scuba-diving: frequency and seriousness about a series of 19 cases]. Ann Fr Anesth Reanim 2008;27:694-9.

44. Cordier PY, Coulange M, Polycarpe A, et al. Immersion pulmonary oedema: a rare cause of life-threatening diving accident. Ann Fr Anesth Reanim 2011;30:699. 
45. Edmonds C, Lippmann J, Lockley S, et al. Scuba divers' pulmonary oedema: recurrences and fatalities. Diving Hyperb Med 2012;42:40-4.

46. Lippmann J, Walker D, Lawrence CL, et al. Provisional report on diving-related fatalities in Australian waters 2007. Diving Hyperb Med 2012;42:151-70.

47. Smart DR, Sage M, Davis FM. Two fatal cases of immersion pulmonary oedema-using dive accident investigation to assist the forensic pathologist. Diving Hyperb Med 2014;44:97-100.

48. Lippmann J, Lawrence C, Fock A, et al. Provisional report on diving-related fatalities in Australian waters 2010. Diving Hyperb Med 2015;45:154-75

49. Fornes P, Lecomte D, Nicolas G. Sudden out-of-hospital coronary death in patients with no previous cardiac history. An analysis of 221 patients studied at autopsy. J Forensic Sci 1993;38:1084-91.

50. Hart G. Exercise-induced cardiac hypertrophy: a substrate for sudden death in athletes? Exp Physiol 2003;88:639-44.

51. Tavora F, Zhang Y, Zhang M, et al. Cardiomegaly is a common arrhythmogenic substrate in adult sudden cardiac deaths, and is associated with obesity. Pathology 2012;44:187-91.

52. Dwyer N, Smart D, Reid DW. Scuba diving, swimming and pulmonary oedema. Intern Med J 2007;37:345-7.

53. Ackerman MJ, Tester DJ, Porter CJ. Swimming, a gene-specific arrhythmogenic trigger for inherited long QT syndrome. Mayo Clin Proc 1999;74:1088-94.
54. Magder S, Linnarsson D, Gullstrand $L$. The effect of swimming on patients with ischemic heart disease. Circulation 1981;63:979-86.

55. Eckart RE, Scoville SL, Campbell CL, et al. Sudden death in young adults: a 25-year review of autopsies in military recruits. Ann Intern Med 2004;141:829-34.

56. Maron BJ, Epstein SE, Roberts WC. Causes of sudden death in competitive athletes. J Am Coll Cardiol 1986;7:204-14.

57. Eckart RE, Shry EA, Burke AP, et al. Sudden death in young adults: an autopsy-based series of a population undergoing active surveillance. J Am Coll Cardiol 2011;58:1254-61.

58. Ullal AJ, Abdelfattah RS, Ashley EA, et al. Hypertrophic cardiomyopathy as a cause of sudden cardiac death in the young: a meta-analysis. Am J Med 2016; 129:486-496.e2.

59. Devereux RB, Alonso DR, Lutas EM, et al. Echocardiographic assessment of left ventricular hypertrophy: comparison to necropsy findings. Am J Cardiol 1986;57:450-8.

60. Marijon E, Bougouin W, Périer MC, et al. Incidence of sports-related sudden death in France by specific sports and sex. JAMA 2013;310:642-3.

61. Denoble PJ, Nelson CL, Ranapurwala SI, et al. Prevalence of cardiomegaly and left ventricular hypertrophy in scuba diving and traffic accident victims. Undersea Hyperb Med 2014;41:127-33.

62. Desai AS, Jhund PS. After TOPCAT: what to do now in Heart Failure with Preserved Ejection Fraction. Eur Heart J 2016. 